\title{
The syndication of private equity investments in South Africa
}

\author{
N. Bent, K. Williams and E. Gilbert* \\ Graduate School of Business, University of Cape Town, \\ Private Bag, Rondebosch 7701, Republic of South Africa \\ gilberte@gsb.uct.ac.za
}

Received September 2004

\begin{abstract}
This paper examines the syndication behaviour of South African private equity and venture capital firms. Three possible rationales for syndication are tested: risk reduction through portfolio diversification (finance rationale), accessing the skills of other firms (resource-based rationale) and improved access to future investment opportunities (deal flow rationale). The finance-based rationale and deal flow rationales are found to be more important than the resource-based rationale. A number of firms additionally list Black Economic Empowerment (BEE) as an additional important reason for syndication. The reasons for syndication behaviour did not vary when small and large firms were considered separately. While firms taking part in start-up investments were more likely to syndicate, their reasons for doing so were not different from those who invest later in the investment life-cycle.
\end{abstract}

While there is currently a low level of syndication of private equity investments in South Africa compared to Europe and the US, most SA firms regard syndication as beneficial and are more likely to syndicate in the future.

The authors would like to thank Gavin Goldblatt, Colin Firer and Trevor Wegner for their helpful comments.

*To whom all correspondence should be addressed.

\section{Introduction}

Syndication refers to the situation where two (or more) venture capital or private equity ${ }^{1}$ firms participate together in an investment opportunity. This may occur at several points during the life cycle of an investment. Three possible rationales for syndication have been suggested: sharing financial risk; accessing the specific resources of other firms; and increasing the flow of deals between private equity firms. As there are costs associated with any syndication (such as the increase in co-ordination costs), this option will only be chosen where the expected value of the exercise exceeds the expected costs of sharing the investment.

The extent of, and rationale(s) for, syndication behaviour has not been established for the South African private equity industry. A survey of private equity firms in this country was conducted to correct for this lack of empirical data. In particular, the relative importance of the three rationales for syndication was established and differences in syndication behaviour related to firm size and stage of investment are tested for. The reasons for firms not engaging in syndication behaviour are also identified. Finally, the attitudes of South African private equity firms towards syndication are examined to establish both its perceived usefulness and

\footnotetext{
${ }^{1}$ Venture capital and private equity firms both provide direct funding to companies wishing to expand. The key difference is that venture capital companies focus on providing funding to new firms (start ups) while private equity companies tend to invest in firms that have an operating history. In this paper private equity will be used as a generic term for both these types of investor firms.
}

whether firms are more (or less) likely to behave in this way in the future.

Section One presents a review of the relevant literature including a discussion of the theoretical rationales for syndication and the extent of its practice both internationally and in South Africa. Section 2 outlines the methodology used in the survey. The findings of the survey are presented in Section 3 and Section 4 outlines the implications of this study for further research efforts and concludes the paper.

\section{Reasons for syndication}

Three primary rationales why a private equity firm may choose to syndicate an investment have been identified (Lockett \& Wright, 2001): firstly, to share financial risk; secondly, to access the specific resources of other firms; and thirdly, to increase the flow of deals between itself and other private equity firms.

\section{Finance-based rationale}

This view is based on the principle of the separation of systematic and unsystematic risk. Unsystematic risk is the risk associated with an individual investment (or firm) and relates to such firm specific factors as the industry in which the firm operates, the growth profile of the firm and the management skills of the entrepreneur. Systematic risk, on the other hand, refers to market related risks. The principle of diversification is based on the idea that by investing in a balanced portfolio of companies, unsystematic risk can be significantly reduced. If a private equity firm holds a fairly 
large portfolio of investments total risk is made up almost entirely of systematic, or market, risk.

In addition, investments by private equity firms are typically less liquid than those in the stock market; these firms will usually commit to invest for a certain minimum period, and in any case would only seek to realise a return on the investment when presented with an attractive exit opportunity. The fact that such investments cannot easily be divested in the short term means that syndication can be used to spread liquidity risk on a deal-by-deal basis.

\section{Resource-based rationale}

The specialised resources of another private equity firm, which are both financial and related to expertise and market information, can be used to reduce company specific risk in the selection stage. When it comes to deciding whether to make the investment, syndication can reduce risk by providing access to a greater set of skills and experience to analyse the investment. The decision of a firm to invest will often be influenced by the willingness of other investors, particularly well-established ones. It is for this reason that the established firms with good reputations often tend to syndicate with each other at the initial stage (Lerner, 1994). The analysis of a potential investment provides information to the firm that reduces uncertainty about the true quality of the project. The quality of this information will depend in part on the experience of the firm. Syndication involves a trade-off between the desire to maintain monopoly profits and the need to gather accurate information on the quality of a project. Where a project is initially brought to a firm for assessment and is considered of low quality, it will be rejected outright as there is little value in seeking a second opinion. On the other hand, where the assessment produces a high expected value, the project will be accepted without need for a second opinion. If it is unclear whether the project should be accepted or rejected a second opinion is valuable. It is here that syndication tends to be undertaken (Amit, Antweiler \& Brander, 2002).

Inexperienced firms are more reluctant to invest on their own, since the signal gained through their own analysis is weaker. They will therefore be more willing to share in the project's surplus through syndication. On the other hand, the signal gained by experienced firms is more precise; they will be reluctant to syndicate and thus have to share in the project profits. As compensation, such firms will require a more precise signal from other potential partners in evaluation of the project, and hence will tend to syndicate with more experienced firms. At a certain stage, the cost of sharing in profits outweighs the benefits of more accurate information and syndication will not take place (Casamatta \& Haritchabalet, 2003).

The second part of the resource-based rationale considers the value added by firms in the ex-post management of investments. In this regard, the availability of a variety of sources of specialised expertise and experience is another rationale for syndication. The investing company may have all the necessary skills to manage the investment, especially if it is a larger, more established firm. It could also bring in third-party expertise. However, it may be beneficial to access skills by syndicating the investment. Different firms have different skills and information, the combination of which could provide value to the investee company.

The type of specific skills required will also vary according to the stage of the investment. Investments at an earlier stage will tend to require more resources from the point of view of the investing company in the form of specific managerial expertise when compared those at the buy-out stage. At this later stage, different specialised management expertise will be required, for example, to guide the financial structuring of the company in anticipation of a stock market listing or some other exit strategy.

\section{Deal flow rationale}

A third reason for syndication identified by firms is the potential for future reciprocity with other private equity firms. By involving another firm in an investment, it is more likely that the originator will be asked to participate in investments in the future by other firms. This factor may be of particular importance when the volume of available investments is small.

\section{Benefits of syndication for the investee company}

There are also reasons for the investee company to prefer that financing is provided by more than a single investor. Firstly, more resources are provided to the investee in the areas of finance, technology, marketing and networking potential; secondly, the chances of additional financing rounds are improved in the case of a strong syndicate, since it would tend to have deep pockets; thirdly, the reputation of the investee is enhanced when a syndicate of established firms comes on board (De Haan, 1999). This is particularly important when a listing is sought. Another reason mentioned is that having more than one investor prevents a single investor from having a major equity share and significant unilateral control over the business, which may give it too much influence over the affairs of the investee (BVCA \& PriceWaterhouseCoopers, 2002).

\section{International syndication behaviour}

A survey of the European private equity industry showed that of the $€ 27,6$ billion invested in 8351 European firms in 2002, more than a quarter of investments were syndicated (European Private Equity and Venture Capital Association, 2003). A survey of 60 firms in the UK indicated that the financial (risk-sharing) motive for syndicating was more important than the resource-based or deal flow rationales (Lockett \& Wright, 2001). The large size of the investment in relation to the size of funds available was the single most important reason for syndication. The deal flow rationale was deemed to be of intermediate significance while the resource-based rationale was found to be of least importance.

This survey was extended to include Belgium, France, Germany, the Netherlands and Sweden, with similar results for each country (Manigart, Lockett, Meuleman, Wright, Landström, Bruining, Desbrières \& Hommel, 2002). The finance-based rationale was significantly more important 
than the other perspectives for all countries. In France, the deal flow rationale was significantly more important than the resource perspective, while in the other countries the results were not significant but tended towards this result. The survey also indicated that firms for whom the resource perspective was more important had a higher propensity to syndicate than firms for whom the financial or deal flow rationales were most important.

Manigart et al. (2002) indicated that over $60 \%$ of venture capital (VC) investments in the US in 2000 were syndicated. This may be partially explained by the fact that the industry in the US is dominated by early stage investments, where syndication may be more likely. When looking at 464 venture capital firms in the US, Bygrave (1987) classified the largest 61 firms as either high innovative, medium innovative or low innovative, based on the types of ventures they had invested over a 16 year period. The results showed that the high innovative VC firms co-invested more than low innovative VC firms, which could be explained by the sharing of information or the sharing of financial risk. The average amount of the investment for the former was only two-thirds of that for the latter. The author concluded that the need to share expertise was a more important motive than the need to share financial risk, since if only financial motive had been relevant, the firms that invested larger amounts per investments would have syndicated more of them. The fact that more specialised knowledge is needed to invest in high innovation projects supports the view that the need to share expertise is the dominant motive. The study also looked at the stage of the investment; the tendency to co-invest was much higher in early stage investments than late-stage investments. Given that there is more uncertainly at the early stage, this supports the view that the sharing of information is a more important motive for syndication than the spreading of risk.

Amit, Antweiler \& Brander (2002) looked at the Canadian venture capital industry and tested the relative importance for syndication of two reasons, namely the benefits gained in the selection process through the provision of a second opinion and the benefits of complementary management skills in the post-investment stage. In terms of the first rationale, it was assumed that the most promising projects would be undertaken as stand-alone projects while those less promising would be syndicated, with the expectation that the returns of the former would be higher than those of the latter. If improved venture selection were the main reason for syndication, syndicated investments should on average have lower returns than stand-alone projects. On the other hand, if the main reason for syndicating was the added value brought to a project through superior management, syndicated investments should have a higher rate of return than stand-alone projects. The results showed that the average return of syndicated investments was higher than those for stand-alone investments, supporting the valueadded hypothesis. This did not mean that the selection effect was not relevant, only that it was less significant than the value-added effect.

\section{Syndication practices in South Africa}

Very little research has been done into the nature and extent of syndication behaviour within the private equity investment field in South Africa. Roberts-Baxter and Stapelberg (2000) when examining the importance of various factors as investment criteria in considering seed or start-up investments, included 'the possibility of syndication' as a factor. Their results indicated that syndication was an important factor, but that an investment would be considered without the possibility of syndication being in place.

\section{Methodology}

Following the example of Lockett and Wright (2001) in the UK and Manigart et al. (2002) for Europe, a questionnaire methodology was adopted. The format of the questionnaire used was derived from these two studies ${ }^{2}$.

The sample was selected from the Southern African Venture Capital and Private Equity Association (SAVCA) member list of entities that are classified as private equity fund managers or that are involved in the management of private equity funds. This listed 45 funds on 1 October 2003. While not all private equity firms in South Africa are SAVCA members, this is the most exhaustive list of firms available and includes all the major players in the industry in South Africa. All of the 45 firms on the SAVCA list were approached for inclusion in the sample. Three were excluded from the population: one firm indicated that it did not invest within South Africa; another revealed that it was not a fund manager but rather invested in other private equity funds; the third had rationalised multiple funds under management into one fund. Another firm had created an additional fund as a separate entity and both were included in the population. This left a total population of 42 firms.

When invited to take part in this survey, 35 firms responded positively and were sent a copy of the questionnaire. Of these, 30 responses were received -22 by way of a telephonic interview and eight by way of an electronic or facsimile return. This corresponds to a $70 \%$ response rate. The total funds under management of the firms contained in these responses were $91 \%$ of the R40.6 billion identified in the 2002 KPMG survey for the private equity industry as a whole.

In terms of the nature of the respondents, $67 \%$ were at managing director/CEO, partner or director level while $17 \%$ were at the investment executive or fund manager level. The remaining responses were from persons at a level also considered to be senior ${ }^{3}$. The overall perspective is thus that the respondents were all senior executives within their firms and involved in deal structuring issues. Consequently, the information provided is believed to be representative of the investment practices of the firms surveyed.

\footnotetext{
${ }^{2}$ Copies of the questionnaire used are available from the authors

${ }^{3}$ These included manager, consultant and financial controller.
} 


\section{Data analysis}

The data was analysed using a combination of the EXCEL and STATISTICA packages. The first step was a description of the extent and nature of the syndication behaviour of the surveyed firms. This was followed by an analysis of the syndication rationale responses which were recorded using a Likert scale of one (very important) to five (very unimportant). This analysis involved three phases: (i) calculation of the mean and median for each individual question within the three rationale categories (finance, resource-base and deal flow); (ii) calculation of a combined measure for each rationale and the mean, median and standard deviation for each of these; and (iii) testing for significant differences between the three combined measures.

As the version of the Likert scale used in the questionnaire can be interpreted as being either an ordinal or an interval measure, the results of both parametric (ANOVA and tetests for means) and non-parametric (Kruskal-Wallis and Wilcoxon signed rank sum medians) tests are reported.

As the relevant tests involve the comparison of measures of central positions (means and medians), two testing strategies were employed. The ANOVA and Kruskal-Wallis tests allow for simultaneous tests for differences in the multiple means and medians respectively. Pair-wise testing of means was also conducted using the t-test for differences in population means for non independent samples and the Wilcoxon signed rank sum test for medians. The first strategy provides a stronger test for differences between multiple means or medians, while the second allows for the ranking of the responses within each different measure of central position.

\section{Construction of composite measures for the three rationales}

Composite measures for each the rationales were created by aggregating the individual responses to the questions under each rationale and then calculating the measure of central position for each rationale. For example, under the Deal Flow Rationale, two questions were asked and the average of the responses for each of these questions was used as a proxy measure for this rationale. This approach has the effect of equally weighting each question when constructing the composite measure.

There are two limitations to this approach. Firstly it causes information contained in the individual responses to be lost. Secondly, factor analysis is a superior approach to creating a representative variable such as this. However the small sample size and limited number of questions making up each rationale precluded this approach from being adopted.

\section{Results}

\section{Syndication practices in South Africa}

\section{Extent of syndication}

The survey indicated that $60 \%$ of the 30 respondent firms had previously syndicated at least one of their investments. In total, the respondent firms had syndicated 65 investments, with the average firm having syndicated slightly more than 4 investments. These results are skewed by two firms which had syndicated 15 and 28 investments each. Removing these two firms gives a mean of 1,57 (median 1,5) investments syndicated per firm. The average investment history for the firms in the sample was six years.

\section{Total investment required per syndicated investment}

In total, specific information of 22 syndicated investments was received. Of these, 19 were under R250 million in size and 15 were of R50 million or under in size. The average size of the investment in which the respondent firm had participated was R237,9 million but this is skewed by three very large investments - two were over R1 billion and the largest was R2,1 billion. The median investment size of R30 million gives a more useful view of central location for all 22 investments. Figure 1 gives the distribution of the total investment made per syndicated investment without the three largest investments. The average investment size excluding the three large investments was R49,2 million and the median figure was R25 million. This can be compared to the average size of investments for all firms in the sample (whether they had syndicated or not), which, once again excluding the same three investments, was R39,9 million. The median figure was also lower at R10 million. This indicates that syndicated investments are generally larger than non-syndicated ones.

\section{Percentage invested in each syndicated investment}

On average, firms that syndicated investments contributed $38 \%$ towards the total investment required per syndicated investment. The minimum contribution was $10 \%$ and the maximum contribution was $60 \%$. The distribution, as shown in Figure 2, indicates a large variation in the contributions made by the firms surveyed.

\section{Reasons for syndication behaviour}

\section{Individual reasons for syndication ${ }^{4}$}

The most important reason for syndicating was the large size of the investment in proportion to the available funds. The two least important reasons were firstly, that the investment was in a sector in which the firm does not usually invest in; and secondly, that the opportunity was outside their usual investment stage. In interviews it was indicated on a number of occasions that firms do not tend to invest outside their area of expertise.

\footnotetext{
${ }^{4}$ Appendix 1 presents the full list of reasons for syndication and their relative rankings.
} 


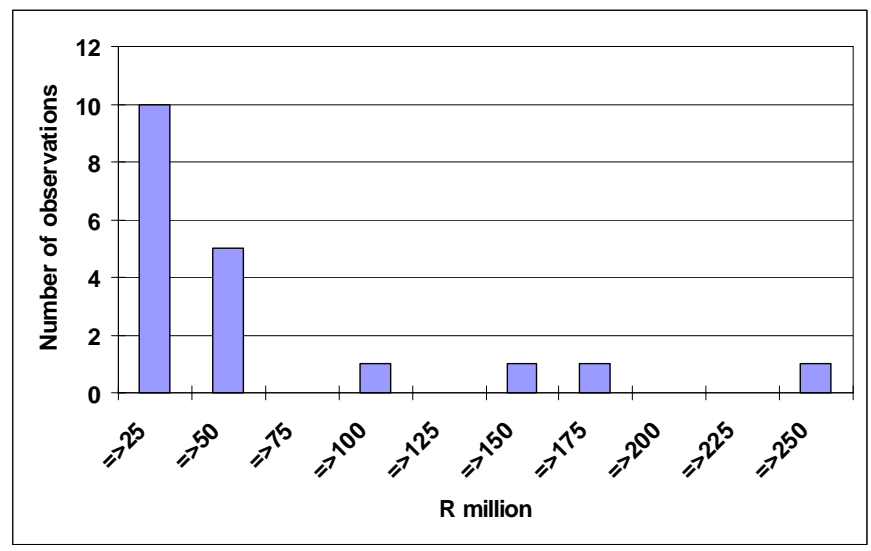

Figure 1: Size of syndicated investments (excluding the three largest investments)

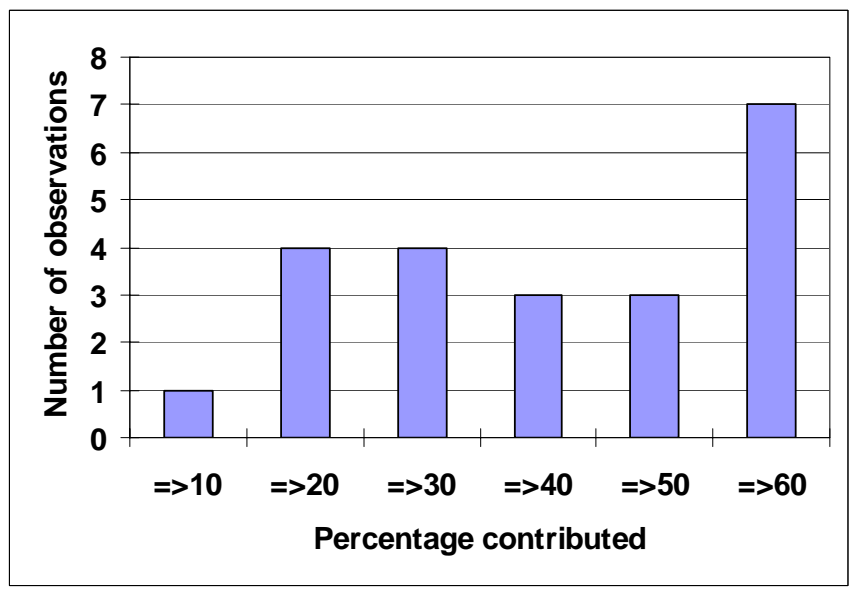

Figure 2: Distribution of percentage contributed in each syndicated investment

The second most important factor overall - the large size of the investment in relation to the firm's average investment size - was also found within the finance-based rationale. The top two reasons for syndicating were thus financebased. The least important reason within the finance-based rationale was the degree of risk associated with the investment. The impression was given in discussions with the respondents that an investment is evaluated within the risk control mechanisms of the firm, and that if it passed these hurdles it was undertaken without the need to further diversify the risk.

Within the resource-based rationale, the need to access specific skills to manage the investment was the most important reason for syndication. This was the fourth ${ }^{5}$ most important factor overall. The reasons relating to different investment stage and sector were the two least important reasons for syndication overall.

The deal flow rationale was perceived to be relatively important to the respondents. Both deal flow related reasons

\footnotetext{
${ }^{5}$ This ranking is based on a comparison of the means. If the medians are compared, the benefit of gaining other firms' advice is the most important factor within this rationale (see Appendix 1).
}

were ranked third overall when comparing the median responses for the question, and third and fifth overall when comparing the means (see Appendix 1).

The respondents were also asked whether there were any reasons for syndicating not covered in the questionnaire. A third of the respondents gave Black Economic Empowerment (BEE) as an additional reason for syndicating investments.

\section{Comparison of rationales for syndication}

Table 1 presents the means and medians for the composite rationale measures. Both of these measures suggest the finance-base rationale to be the most important reason for syndication and the resource-based rationale to be the least important.

The results of ANOVA and the Kruskal-Wallis tests are reported in Table 2 . These results both suggest that there are significant differences between the measures of central positions of the three composite rationale measures.

In order to establish which composite rationale measure was more important, pair-wise testing of the three combined rationale measures was conducted. Table 3 contains the results.

This analysis indicates that both the finance-based and the deal flow rationales were significantly more important than the resource-based rationale. When comparing the finance and the deal flow rationales, both the mean and median for the finance-based rationale was lower (more important), but this difference was not statistically significant.

\section{Syndication and investment size}

The tendency to syndicate and reasons for doing so were also looked at with reference to the average size of the firms' investments. The firms were divided into those that invested on average less than R40 million per investment (small firms) and those that invested more than this amount (large firms). This break point was selected so that the number of firms which had syndicated in each category would be roughly equal. Of the 21 firms that invested R40 million or less on average per investment, nine had participated in syndication. Of the eight firms that invested over R40 million per investment, all had previously syndicated investments. The results for the three rationales for the small and large firm groups are reported in Table 4 as are the tests of the these comparative means and medians.

The results show that although the large firms were more likely to syndicate than the small firms, their reasons for doing so were not significantly different. 
Table 1: Measures of central location for the three aggregate rationale variables

\begin{tabular}{ccccc}
\hline Combined Rationale Variable & N & Mean & Median & Rank \\
\hline Finance-based & 18 & 2,88 & 2,50 & 1 \\
Resource-based & 18 & 3,78 & 3 & 3,00 \\
Deal flow & 17 & 3,03 & 2 & 3,00 \\
\hline
\end{tabular}

Table 2: Joint tests for differences in the rationales for syndication

\begin{tabular}{|c|c|c|c|c|}
\hline Rationale & Mean & ANOVA results & Median & Kruskal-Wallis result \\
\hline Finance-based & $2,96^{\mathrm{a}}$ & \multirow{3}{*}{$\begin{array}{c}\text { p-value: } 0,0544 \\
\text { Significance level: } 10 \%\end{array}$} & 2,5 & \multirow{3}{*}{$\begin{array}{c}\text { p-value: } 0,0273 \\
\text { Significance level: } 5 \%\end{array}$} \\
\hline Resource-based & $3,77^{\mathrm{a}}$ & & 4,0 & \\
\hline Deal Flow & 3,03 & & 3,0 & \\
\hline
\end{tabular}

Table 3: Pair-wise tests for differences in the means and medians of the composite rationale variables

\begin{tabular}{cccc}
\hline $\begin{array}{c}\text { Composite rationale } \\
\text { measures compared }\end{array}$ & $\begin{array}{c}\text { t-test for population difference for non } \\
\text { independent samples - one tailed (means) } \\
\text { Significance level } \\
\text { p-value }\end{array}$ & $1 \%$ & $\begin{array}{c}\text { Wilcoxon Signed Rank Sum Test - one tailed } \\
\text { (medians) } \\
\text { Significance level }\end{array}$ \\
\hline $\begin{array}{c}\text { Finance-based vs. } \\
\text { Resources-based } \\
\text { Resources-based vs. Deal } \\
\text { Flow }\end{array}$ & 0,0059 & $5 \%$ & 0,0057 \\
$\begin{array}{c}\text { Finance-based vs. Deal } \\
\text { Flow }\end{array}$ & 0,0152 & Not significant & 0,0066 \\
$1 \%$ \\
\hline
\end{tabular}

Table 4: Comparison of rationales for syndication: Small vs. Large firms

\begin{tabular}{cccccccc}
\hline & \multicolumn{4}{c}{ Comparison of rationale means (t-test assuming equal variances - two tailed) and } \\
medians (Wilcoxon Rank Sum test - two tailed)
\end{tabular}

\section{Syndication and investment stage}

Syndication behaviour was also considered in relation to the stage of investment. The firms that had previously syndicated investments were divided into two categories: those that invested the majority of their investments at either the venture capital or development capital stage (early stage), and those that invested the majority of their funds at the buy-out stage (late stage). A comparison of the values of the means and medians suggests that the finance and resource-based rationales are more important for those firms that invest at the venture capital stage than those that invest at the buy-out stage. However, as in shown in Table 5, there is no statistical evidence ${ }^{6}$ of significant differences between those firms that invest mainly at the venture or development

\footnotetext{
${ }^{6}$ The strength of these tests is, however, negatively affected by their small sample size.
}

capital stage and those that invest mainly at the buy-out stage.

\section{Reasons for not syndicating}

The reasons for firms not participating in syndication were also addressed in the survey. ${ }^{7}$ The responses indicate that the most important reason for not syndicating investments was the small size of potential investments. The least important reason for not syndicating investments was that there were no past investments to reciprocate.

The finance-based rationale contains three of the top four individual reasons for not syndicating based on the mean figure, namely the small investment size, the desire to keep attractive investments to oneself and the large number of

\footnotetext{
${ }^{7}$ Appendix 2 contains the full set of reasons for not syndicating and their relative rankings
} 
funds available compared to the small number of available investments. The degree of risk associated with the investment was once again viewed as unimportant.

From the resource-based rationale the investments being at a stage in which the firms have expertise was the most important reason for not syndicating and was the third most important reason overall. The least important reason was that no outside skills or experts are required to manage the investment.

Responses to questions in the deal flow category suggest that this was generally seen as an unimportant rationale for not syndicating. This indicates that some measure of reciprocation is already seen among firms.

Table 6 presents the alternative measures of central position for the non-syndication firms' aggregate rationale variable. The results indicate that the finance-based rationale was the most important as regards not engaging in syndication, while the deal flow rationale was the least important. The validity of these rankings is tested using the same approach used for the syndication composite rationale variables reported above.

The results of the ANOVA and the Kruskal-Wallis joint tests of these three variables are reported in Table 7. They both indicate that there is strong evidence of significant differences between the measures of central positions of the three composite non-syndication rationale measures.

Table 8 presents the results of the pair-wise tests of the composite non-syndication composite rationale variables' means and medians.

The finance-based composite rationale measure had the lowest aggregate mean and median scores and was found to be significantly lower (more important) than the deal flow rationale for both these measures. Both the mean and median of the resource-based rationale were significantly lower (more important) than those of the deal flow rationale. The mean of the finance-based composite rationale measure was also found to be significantly lower than the mean of the resource-based composite variable (at the $10 \%$ level however), but the difference in medians between these two variables was not significant. The presence of the top three individual reasons for non-syndication behaviour in the finance-based category also suggests that this rationale is more important than the resource-based rationale - but the evidence for this conclusion is not strong.

In terms of other reasons for not syndicating, several of the firms mentioned their aversion to giving up control of the investment, while others mentioned the increase in coordination costs with multiple partners, especially since firms had different agendas and investment philosophies.

\section{Views on syndication}

Of the 12 firms that had not syndicated any of their previous investments, ten of these indicated that they had considered syndication on previous occasions. All respondents were asked whether they regarded syndication as beneficial for each of the three primary motives outlined earlier. The overall impression was that syndication was viewed in a positive light. Each of the three motivations for syndication was viewed as beneficial by more than $70 \%$ of the firms.

The respondents were also asked whether they believed they would be more likely or less likely to engage in syndication in the future. More than three quarters of respondents indicated that they thought their firm would be more likely to syndicate investments in the future.

\section{Implications for future research}

Given that the resource-based rationale for syndication is not considered important for VC firms in South Africa, an examination of how firms are best able to add value in the management of investments would be instructive. A case study approach may be particularly useful in this regard. More generally, the collection of comparative data on the sources of returns of syndicated investments (as opposed to stand-alone investments) would be very valuable.

A comparative study of syndication practices in South Africa and the US would yield interesting insights as to why syndication is so much more prevalent in the latter country. Valuable lessons may be available as to how firms have reduced the co-ordination costs implied in working together.

Finally, it would be useful to consider syndication from the side of the investee firm, since value is added by outside investors through existing management. This would include considerations of the ideal number and combination of investors, and of which particular skill sets are most valued by the insiders. This would lead to a better understanding of how private equity firms and investee firms are able to combine their skills.

\section{Conclusion}

This study shows that South African private equity firms syndicate their investments primarily because of the large size of the investment in relation to the amount of funds available and the average investment size. This contributed to the finance-based rationale being the most important overall motivation for their syndication behaviour. This conclusion was not different for firms with large or small average investments or for firms which invest at different stages of the investment lifecycle.

Where firms had elected not to syndicate, they had done so primarily due to the small investment size and the desire to keep attractive investments to themselves. The idea that reciprocation of investments with other firms was unlikely was not regarded as an important reason for not engaging in syndication. 
Table 5: Comparison of rationales for syndication: Early vs. Late Stage firms

\begin{tabular}{|c|c|c|c|c|c|c|c|}
\hline \multicolumn{8}{|c|}{$\begin{array}{l}\text { Comparison of rationale means (t-test assuming equal variances - two tailed) and } \\
\text { medians (Wilcoxon Rank Sum test - two tailed) }\end{array}$} \\
\hline & & \multicolumn{2}{|c|}{ Finance-based rationale } & \multicolumn{2}{|c|}{ Resource-based rationale } & \multicolumn{2}{|c|}{ Deal flow rationale } \\
\hline & $\mathrm{N}$ & Mean & Median & Mean & Median & Mean & Median \\
\hline Early stage firms & 7 & 2,5714 & 2,5 & 3,3429 & 4,0 & 3,0833 & 4.0 \\
\hline Late stage firms & 8 & 2,8542 & 2,75 & 4,0417 & 4,25 & 3,3750 & 4.25 \\
\hline & p-value & 0,5581 & 0,817 & 0,1156 & 0,1832 & 0,6330 & 0,5186 \\
\hline \multicolumn{2}{|c|}{ Significance level } & \multicolumn{4}{|c|}{ Not Significant } & & \\
\hline
\end{tabular}

Table 6: Measures of central location for the non-syndication composite rationale variables

\begin{tabular}{llccc}
\hline \multicolumn{1}{c}{ Combined Rationale Variable } & N & Mean & Median & Rank \\
\hline Finance-based & 29 & 2,6839 & 2,5 & 1 \\
Resource-based & 29 & 2,9569 & 3,0 & 2 \\
Deal flow & 29 & 3,5172 & 4,0 & 3 \\
\hline
\end{tabular}

Table 7: Joint tests for differences in the non-syndication composite rationale variables

\begin{tabular}{lcccc}
\hline \multicolumn{1}{c}{ Rationale } & Mean & ANOVA results & Median & Kruskal-Wallis result \\
\hline Finance-based & 2,6839 & p-value: 0,0035 & 2,5 & p-value: 0,0075 \\
Resource-based & 2,9569 & Significance level: $1 \%$ & 3,0 & Significance level: $1 \%$ \\
Deal Flow & 3,5172 & 4,0 & L
\end{tabular}

Table 8: Test for differences in the means and medians of the non-syndication composite rationale variables

\begin{tabular}{lcccc}
\hline \multicolumn{1}{c}{$\begin{array}{c}\text { Composite rationale } \\
\text { measures compared }\end{array}$} & \multicolumn{2}{c}{$\begin{array}{c}\text { t-test for population difference for non } \\
\text { independent samples (means) } \\
\text { p-value }\end{array}$} & Significance level & Wilcoxon Signed Rank Sum Test (medians) \\
\hline $\begin{array}{l}\text { Finance-based vs. } \\
\text { Resources-based }\end{array}$ & 0,0821 & $10 \%$ & 0,1435 & Significance level \\
$\begin{array}{l}\text { Resources-based vs. Deal } \\
\text { Flow }\end{array}$ & 0,0112 & $5 \%$ & 0,0132 & $5 \%$ \\
$\begin{array}{l}\text { Finance-based vs. Deal } \\
\text { Flow }\end{array}$ & 0,0014 & $1 \%$ & 0,0021 & $1 \%$ \\
\hline
\end{tabular}

Syndication does entail an increase in co-ordination costs but it is submitted that these are partly 'one-off' costs - some of the effort relates to the need to get to know the investment style of other firms and the way in which they supervise their investments. A habit of working with other firms should minimise these costs over time. The strong tendency to syndicate in the US would tend to confirm this view.

Syndicated investments generally have higher rates of return than stand-alone investments, implying that the involvement of multiple firms in the management of the investment is a value-adding exercise. One of the challenges for the industry would therefore appear to be an improved climate of networking and better sharing of expertise. Firms recognise the benefits that these aspects can bring to investing but should be more willing to put them into practice.

The discrepancy between the firms' general views on syndication and the extent to which they had syndicated in the past was unexpected. While more than three quarters of the respondent firms believed they would be more likely to syndicate in the future, and more than $70 \%$ viewed each of the three primary reasons as important, an extrapolation of past trends indicates that in the past year less than $13 \%$ of investments had been syndicated. Excluding two of the firms from the sample, this figure was reduced to around $5 \%$. This is markedly different to the situation in Europe and the US, where the figures from recent years were $25 \%$ and $60 \%$ respectively.

\section{References}

Amit, R., Antweiler, W. \& Brander, J.A. 2002. 'Venture capital syndication: Improved venture selection vs. the value-added hypothesis', Journal of Economics \& Management Strategy, 11(3): 423-452.

BVCA \& PriceWaterhouseCoopers. 2002. 'A guide to private equity’.[online] URL: http://www.bvca.co.uk. Accessed 20 July 2003.

Bygrave, W. 1987. 'Syndicated investments by venture capital firms: A networking perspective', Journal of Business Venturing, 2:139-154. 
Casamatta, C. \& Haritchabalet. C. 2003. 'Learning and syndication in venture capital investments' Centre de Recherche en Gestion no. 2003 - 157. [online] URL: http://www.univ-tlse1 fr/iae/files/159 pdf.pdf.

De Haan, M. 1999. 'International syndication’. In Bygrave, W., Hay, M. \& Peeters, J. (Eds.). 1999. The venture capital handbook. London: Pearson Education Limited, pp. 281294.

European Private Equity and Venture Capital Association. 2003. Newsletter, September 2003. [online] URL:www.evca.com/images/attachments/

tmpl_9_art_65_att_380.pdf. Accessed 10 October 2003.

Lerner, J. 1994. 'The syndication of venture capital investments', Financial Management, 23(3):16-27.

Lockett, A. \& M. Wright. 2001. 'The syndication of venture capital investments', OMEGA: The International Journal of Management Science, 29:375-390.

Manigart, S., Lockett, A., Meuleman, M., Wright, M. Landström, H., Bruining, H., Desbrières, P. \& Hommel, U. 2002. The syndication of venture capital investments in Europe: Evidence from five European countries. Université de Bourgogne Working Papers FARGO number 1021202.

Roberts-Baxter, G. \& Stapelberg, C. 2000. 'An exploratory study into the availability and provision of seed and start-up capital in South Africa'. MBA Research Report, Graduate School of Business, University of Cape Town. 


\section{Appendix 1: Reasons for Syndicating}

\begin{tabular}{|c|c|c|c|c|c|}
\hline a. Finance-based rationale & $\mathrm{N}$ & Mean & Rank & Median & Rank \\
\hline i. The large size of the deal in proportion to the available funds & 18 & 2,28 & 1 & 1,5 & 1 \\
\hline ii. The requirement for additional rounds of financing & 17 & 3,18 & 5 & 4 & 6 \\
\hline iii. The large size of the deal in proportion to the firms average deal size & 18 & 2,61 & 2 & 2 & 2 \\
\hline iv. The high degree of specific risk associated with the deal & 17 & 3,47 & 8 & 4 & 6 \\
\hline \multicolumn{6}{|l|}{ b. Resource-based rationale } \\
\hline i. The need to access specific skills to manage the investment & 18 & 3,06 & 4 & 4 & 6 \\
\hline ii. The difficulty in finding effective management in the industry & 18 & 3,61 & 9 & 4 & 6 \\
\hline iii. The deal is outside your usual investment stage & 17 & 4,29 & 11 & 5 & 11 \\
\hline iv. The deal is in a sector you don't usually invest in & 16 & 4,50 & 12 & 5 & 11 \\
\hline v. The deal is in a different geographical location to your usual investment & 18 & 3,89 & 10 & 4 & 6 \\
\hline vi. The benefit of gaining the advice of other firms before investing & 18 & 3,44 & 7 & 3,5 & 5 \\
\hline \multicolumn{6}{|l|}{ c. Deal flow rationale } \\
\hline i. The possibility of future reciprocation of deals & 17 & 2,88 & 3 & 3 & 3 \\
\hline ii. The reciprocation of past deals & 17 & 3,18 & 5 & 3 & 3 \\
\hline
\end{tabular}

Note: scale: 1 = very important; 2 = important; 3 = average; 4 = unimportant; 5 = very unimportant.

\section{Appendix 2: Reasons for not syndicating}

\begin{tabular}{|c|c|c|c|c|c|}
\hline a. Finance-based rationale & $\mathrm{N}$ & Mean & Rank & Median & Rank \\
\hline i. The small size of the deals & 28 & 1,79 & 1 & 1,50 & 1 \\
\hline ii. The desire to keep attractive investments to yourself & 29 & 2,48 & 2 & 2,00 & 2 \\
\hline $\begin{array}{l}\text { iii. The large amount of funds available for investing compared to the small number } \\
\text { of potential investments }\end{array}$ & 29 & 2,86 & 4 & 3,00 & 4 \\
\hline iv. The low degree of risk associated with the deals & 29 & 3,55 & 9 & 4,00 & 8 \\
\hline \multicolumn{6}{|l|}{ b. Resource-based rationale } \\
\hline i. No outside skills or experts are required to manage your investments & 29 & 3,24 & 7 & 3,00 & 4 \\
\hline ii. Your investments are at an investment stage in which you have expertise & 29 & 2,59 & 3 & 2,00 & 2 \\
\hline iv. Your investments are in a sector in which you have expertise & 29 & 2,97 & 5 & 3,00 & 4 \\
\hline v. Your investments are in your usual geographical location & 28 & 3,07 & 6 & 3,00 & 4 \\
\hline \multicolumn{6}{|l|}{ c. Deal flow rationale } \\
\hline i. There is little or no possibility of future reciprocation of deals & 29 & 3,48 & 8 & 4,00 & 8 \\
\hline ii. There are no past deals to reciprocate & 27 & 3,67 & 10 & 4,00 & 8 \\
\hline
\end{tabular}

Note: scale: 1 = very important; 2 = important; 3 = average; 4 = unimportant; 5 = very unimportant. 